\title{
Low-sodium Cheddar cheese: Effect of fortification of cheese milk with ultrafiltration retentate and high-hydrostatic pressure treatment of cheese
}

\author{
M. Ozturk, ${ }^{*}$ S. Govindasamy-Lucey, $\dagger^{1}$ J. J. Jaeggi, $\dagger$ M. E. Johnson, $\dagger$ and J. A. Lucey ${ }^{\star} \dagger$ \\ *Department of Food Science, and \\ †Wisconsin Center for Dairy Research, University of Wisconsin, Madison 53706
}

\begin{abstract}
Low-sodium cheeses often exhibit an acidic flavor due to excessive acid production during the manufacturing and the initial stage of ripening, which is caused by ongoing starter culture activity facilitated by the low salt-in-moisture levels. We proposed that this excessive starter-induced acidity could be prevented by the fortification of cheese milk with ultrafiltration (UF) retentates (to increase curd buffering), and by decreasing microbial activity using the application of high-hydrostatic pressure (HHP) treatment (that is, to reduce residual starter numbers). Camel chymosin was also used as a coagulant to help reduce bitterness development (a common defect in low-sodium cheeses). Three types of low-Na $(0.8 \% \mathrm{NaCl})$ Cheddar cheeses were manufactured: non-UF fortified, no HHP applied (L-Na); UF-fortified (cheese milk total solids $=17.2 \pm$ $0.6 \%$ ), no HHP applied (L-Na-UF); and UF-fortified, HHP-treated (L-Na-UF-HHP; $500 \mathrm{MPa}$ for $3 \mathrm{~min}$ applied at $1 \mathrm{~d}$ post-cheese manufacture). Regular salt $(2 \% \mathrm{NaCl})$ non-UF fortified, non-HHP treated (R-Na) cheese was also manufactured for comparison purposes. Analysis was performed at $4 \mathrm{~d}, 2 \mathrm{wk}$, and 1, 3, and 6 mo after cheese manufacture. Cheese functionality during ripening was assessed using texture profile analysis and dynamic low-amplitude oscillatory rheology. Sensory Spectrum and quantitative descriptive analysis was conducted with 9 trained panelists to evaluate texture and flavor attributes using a 15-point scale. At $4 \mathrm{~d}$ and 2 wk of ripening, L-Na-UF-HHP cheese had $\sim 2$ and $\sim 4.5 \log$ lower starter culture numbers, respectively, than all other cheeses. Retentate fortification of cheese milk and HHP treatment resulted in low-Na cheeses having similar insoluble calcium concentrations and $\mathrm{pH}$ values compared with $\mathrm{R}-\mathrm{Na}$ cheese during ripening. The L-Na-UF cheese exhibited significantly higher hardness values (measured by texture profile analysis) compared with L-Na cheese until 1 mo of ripening; however, after
\end{abstract}

Received March 6, 2015.

Accepted June 19, 2015.

${ }^{1}$ Corresponding author: rani@cdr.wisc.edu
1 mo, all low-Na cheeses exhibited similar hardness values, which were significantly lower than R-Na cheese. Pressure treatment significantly increased maximum loss tangent (meltability) from rheology testing and decreased melt temperature. Sensory results indicated only very slight bitterness ( $<2.5$ out of 15 -point scale) was detected in all cheeses during the 6 mo of ripening. The L-Na-UF-HHP cheese did not significantly differ in bitterness and acidity from $\mathrm{R}-\mathrm{Na}$ cheese during ripening. Pressures treatment of cheese at $500 \mathrm{MPa}$ and cheese milk retentate fortification could be used to improve the quality of low-Na cheese.

Key words: high-pressure processing, milk retentate, low sodium cheese

\section{INTRODUCTION}

Concerns over a possible relationship between dietary sodium intake and cardiovascular disease have led to an effort to reduce salt in processed foods (US Department of Health and Human Services, 2005), although the long-term health effects of high salt consumption have yet to be conclusively demonstrated (Taylor et al., 2011). Reducing salt in cheese is challenging because salt assists manufacturers in controlling various important cheese parameters, including final moisture content, microbial activity, survival of the starter bacteria, and residual enzymatic activity (Johnson et al., 2009). Salt content of cheese also directly influences flavor and texture, with reduced-salt cheeses often reported to be softer, bitter, acidic, and pasty (Guinee, 2004). In addition, salt also has an indirect effect on flavor of cheese through its influence on chymosin activity; decreasing the $\mathrm{NaCl}$ levels in cheese facilitates chymosin action on $\beta-\mathrm{CN}$, and thus the production of hydrophobic peptides from the C-terminal of $\beta$-CN (e.g., $\beta-\mathrm{CN}$ f193-209), which are extremely bitter (Kelly et al., 1996).

Several previous studies have investigated the effect of reducing the sodium content and partial or complete replacement of sodium with other salts on the quality of Cheddar cheese. Lindsay et al. (1982) studied Cheddar cheese manufactured with either $\mathrm{NaCl}$ or a 1:1 blend of $\mathrm{NaCl}$ and $\mathrm{KCl}$ at various final salt levels 
$(1.25,1.5$, and $1.75 \%)$. Cheeses made with $\mathrm{NaCl}$ and $\mathrm{KCl}$ blends received lower overall acceptability scores and exhibited higher bitterness and lipolysis compared with the cheeses made with $\mathrm{NaCl}$ alone (at the same total salt level). Grummer et al. (2013) investigated the partial $(60 \%)$ replacement of $\mathrm{NaCl}$ with $\mathrm{KCl}$ with and without flavor enhancers. They reported that low-Na cheeses made with $\mathrm{NaCl}$ and $\mathrm{KCl}$ blends were well liked by the sensory panelists and were comparable to the control cheese (which contained only $\mathrm{NaCl}$ ). However, the type of flavor enhancers used either positively or negatively affected the quality of reduced- $\mathrm{NaCl}$ cheese. However, unintended consequences may occur for a sizable subpopulation in the United States if $\mathrm{KCl}$ is used widely and at high levels, especially because the $\mathrm{K}$ content of foods is not generally provided in label information. Adverse cardiac effects (arrhythmias) can result from hyperkalemia, which is a markedly elevated serum level of $\mathrm{K}$ in individuals whose urinary $\mathrm{K}$ excretion is impaired by a medical condition, drug therapy, or both; instances of life-threatening hyperkalemia have been reported (IOM, 2005). Kosikowski (1983) used a different approach rather than replacing $\mathrm{Na}$, by fortifying cheese milk with UF retentate for the manufacture of reduced-salt $(\sim 1 \%)$ Cheddar cheese. Control cheese $(1 \% \mathrm{NaCl}$, with no UF retentate fortification) was acidic, bitter, pasty, and lacked typical Cheddar cheese flavor, whereas cheeses fortified with UF retentate exhibited good to excellent quality, probably due at least partially to their higher $\mathrm{pH}$ values.

Application of high-hydrostatic pressure (HHP) processing to cheese influences microflora levels, acid development, proteolysis, and protein-protein interactions (Martinez-Rodriguez et al., 2012). Ozturk et al. (2013b) investigated the effect of HHP on regular- $(5.3 \%)$, reduced- $(2.5 \%)$, low- $(1.9 \%)$, and no- NaCl $(0.2 \%)$ added Cheddar cheeses. One week after manufacture, cheeses were subjected to HHP of $\sim 405 \mathrm{MPa}$ for $3 \mathrm{~min}$. No significant differences were noted in proteolysis, $\mathrm{pH}$ values, or sensory profiles of cheeses made with the same $\mathrm{NaCl}$ levels. It is known that the effects of HHP on cheese primarily depend on the pressure and time treatment and the age of the cheese when the HHP treatment is applied (Juan et al., 2007). Juan et al. (2007) reported that cheeses that were HHP treated at $1 \mathrm{~d}$ had higher $\mathrm{pH}$ values than nontreated cheeses, whereas cheeses that were HHP treated at $15 \mathrm{~d}$ did not exhibit any $\mathrm{pH}$ differences compared with nontreated cheese. This was probably because most lactose was fermented by $15 \mathrm{~d}$ of ripening. Previous studies indicated that pressures $>400 \mathrm{MPa}$ resulted in lower levels of lactic acid and proteolysis (via decreased residual activity of chymosin and bacterial proteinases; Malone et al., 2003; Juan et al., 2007).
It is generally agreed that the activity of residual coagulant plays a major role in bitterness development in cheese (Guinee and Fox, 2004; Grant, 2011). A novel type of coagulant (i.e., fermentation-produced camel chymosin) that had less residual proteolytic activity in cheese was successfully used to decrease bitterness in low-fat (Govindasamy-Lucey et al., 2010) and lowsodium cheeses (Grant, 2011; Moller et al., 2013). Therefore, we hypothesized that a further reduction in the activity of residual coagulant due to HHP treatment could assist in the production of good-quality low-sodium Cheddar cheese. In the current study, we wanted to investigate a combination of approaches involving cheese milk fortification with UF retentate, along with HHP treatment of cheese, on the properties of low-sodium Cheddar cheeses manufactured with fermentation produced camel chymosin.

\section{MATERIALS AND METHODS}

\section{UF of Milk}

Raw whole milk was obtained from the University of Wisconsin-Madison dairy plant on $2 \mathrm{~d}$ before cheesemaking. Low-concentration-factor UF was performed on whole milk to approximately $27.5 \%$ TS $(7.7 \% \mathrm{CN})$. The low-concentration-factor UF was performed at less than $7^{\circ} \mathrm{C}$, by recirculation through a UF unit (modified APV North America Inc., Tonawanda, NY) fitted with 4 spiral-wound, polyethersulfone membranes (model ST3B4338, Synder Filtration, Vacaville, CA). Each membrane had a molecular weight cut-off of 10,000 Da and the total membrane area was $32.8 \mathrm{~m}^{2}$. The retentates were then stored overnight at $4^{\circ} \mathrm{C}$ and blended to the specified $\mathrm{CN}$ content (4\%) and CN-to-fat ratio the following morning to give standardized cheese milks.

\section{Cheese Manufacture}

Licensed Wisconsin cheesemakers manufactured 5 independent batches of milled-curd Cheddar cheeses at the University of Wisconsin-Madison dairy processing plant. On each cheesemaking day, 4 square, jacketed stainless steel open cheese vats (Stoelting LV60, Kiel, WI), with a maximum capacity of $272 \mathrm{~kg}$ of milk, were used to manufacture 2 salt-in-moisture (S/M) level cheeses. Cheese milk $(12.4 \pm 1.5 \%$ TS, $2.4 \pm 0.3 \% \mathrm{CN}$, $3.7 \pm 0.5 \%$ fat) in 2 vats were fortified with UF retentate $(27.5 \pm 1.5 \% \mathrm{TS}, 7.7 \pm 0.3 \% \mathrm{CN}, 11.6 \pm 0.5 \%$ fat $)$ to give blended cheese milk $(17.2 \pm 0.6 \% \mathrm{TS}, 4.0$ $\pm 0.1 \% \mathrm{CN}, 6.5 \pm 0.2 \%$ fat). For 2 unfortified vats, 227 $\mathrm{kg}$ of cheese milk was used, whereas the 2 UF-fortified cheeses were manufactured with $125 \mathrm{~kg}$ of cheese milk. This was done to produce similar final curd weights 
Table 1. Cheese milk composition (mean $\pm \mathrm{SD}$ ) and cheese manufacturing procedures that were used to manufacture experimental milled-curd Cheddar cheeses

\begin{tabular}{|c|c|c|c|c|}
\hline Item & Regular $\mathrm{NaCl}$ & Low $\mathrm{NaCl}$ & $\begin{array}{l}\text { Low } \mathrm{NaCl} \text {, } \\
\text { UF-fortified }\end{array}$ & $\begin{array}{l}\text { Low NaCl, } \\
\text { UF-fortified }^{1}\end{array}$ \\
\hline TS $(\%)$ & $11.8 \pm 0.5$ & $11.8 \pm 0.5$ & $17.2 \pm 0.6$ & $17.2 \pm 0.6$ \\
\hline Ripening times $(\min )$ & 60 & 60 & 60 & 60 \\
\hline Cutting the gel (extra passes) & 3 & 15 & 15 & 15 \\
\hline Stacking procedure during Cheddaring & With stacking & $\begin{array}{l}\text { Single layer } \\
\text { (no stacking) }\end{array}$ & $\begin{array}{l}\text { Single layer } \\
\text { (no stacking) }\end{array}$ & $\begin{array}{l}\text { Single layer } \\
\text { (no stacking) }\end{array}$ \\
\hline Wait time between salting and hooping (min) & 20 & 80 & 80 & 80 \\
\hline Salt ( $\mathrm{g}$ of $\mathrm{NaCl} / \mathrm{kg}$ of cheese curd) & 53.1 & 9.4 & 9.4 & 9.4 \\
\hline
\end{tabular}

${ }^{1}$ Cheeses obtained from this vat were subjected to high-hydrostatic pressure of $500 \mathrm{MPa}$ for 3 min at $6.4 \pm 1^{\circ} \mathrm{C}$ at $1 \mathrm{~d}$ after manufacture.

in addition to keeping starter culture and coagulant ratios (based on $\mathrm{CN}$ content) constant for the control and experimental variables. The average composition of the cheese milks for each vat and the manufacturing procedures are given in Table 1. Retentate-fortified cheese milk tended to clot faster, thus lower $\left(26.7^{\circ} \mathrm{C}\right)$ ripening (gel-forming) temperatures were used to adjust (lengthen) the cutting time. Cheesemaking procedures (i.e., ripening temperatures, curd size, waiting time between salt application, and waiting time between salting and hooping; Table 1) were modified to try to obtain similar moisture contents among the different $\mathrm{NaCl}$ level cheeses.

Direct vat-set starter culture, containing Lactococcus lactis ssp. lactis and Lactococcus lactis ssp. cremoris blend (MA11, DuPont Danisco, Madison, WI), was added at the rate of $10 \mathrm{~g}$ for $227 \mathrm{~kg}$ of unfortified milk or $125 \mathrm{~kg}$ of UF-fortified milk and ripened as outlined in Table 1. Fermentation-produced camel chymosin (Chymax M, Chr. Hansen, Milwaukee, WI) was used as coagulant at the rate of $11.3 \mathrm{~g}$ for $227 \mathrm{~kg}$ of unfortified milk or $125 \mathrm{~kg}$ of UF-fortified milk $(2.05 \pm 0.5 \mathrm{~g}$ of chymosin $/ \mathrm{kg}$ of $\mathrm{CN})$. The coagula were cut on similar firmness ( 20 min) as evaluated subjectively by an experienced licensed Wisconsin cheesemaker. The coagulum was cut with a 6.35 -mm vertical wire curd knife at pH $6.55 \pm 0.04$. A previous study (Ozturk et al., 2013b) carried out in our laboratory indicated that moisture content of cheese increased with a decrease in the $\mathrm{NaCl}$ content. Thus, as an attempt to keep the moisture levels constant over the 2 different salt levels, the coagula from the low- $\mathrm{NaCl}$ cheeses were cut finer into rice-sized curds compared with the regular- $\mathrm{NaCl}$ cheeses. Curds were cooked and stirred at $39^{\circ} \mathrm{C}$ until the curd reached $\mathrm{pH}$ around 6.05, then the whey was drained. Cheese slabs were cheddared, stacked 2 high (except for the low- $\mathrm{NaCl}$ cheeses, which were not stacked), and milled at a $\mathrm{pH}$ of $5.53 \pm 0.02$. Appropriate amounts of $\mathrm{NaCl}$ were added in 3 incremental saltings (Table 1) to ob- tain the target salt contents. Cheeses were hooped and then pressed at $414 \mathrm{kPa}$ for $4 \mathrm{~h}$. Cheeses were vacuum packaged and ripened for $6 \mathrm{mo}$ at $7^{\circ} \mathrm{C}$ and analyzed at $4 \mathrm{~d}, 2 \mathrm{wk}$, and 1, 3, and 6 mo.

\section{High-Pressure Treatment}

One day after manufacture, 1 block (approximately $35 \times 28 \times 8.5 \mathrm{~cm}$ ) of the low-NaCl, UF-fortified cheeses were HHP treated at $500 \mathrm{MPa}$ for 3 min at a temperature of $6.4 \pm 1^{\circ} \mathrm{C}$. Water was used as the pressure transfer medium. High-pressure unit (Avure Ultra 215 L, Avure Technologies Inc., Kent, WA) reached $500 \mathrm{MPa}$ in around $120 \mathrm{~s}$. During the compression, the temperature of the water in holding tank increased from about 5.4 to $7.4^{\circ} \mathrm{C}$. The decompression cycle took about $30 \mathrm{~s}$.

\section{Compositional Analyses}

The UF retentate and cheese milk were analyzed for TS (Green and Park, 1980), fat (Mojonnier method; AOAC International, 2000), protein (total percentage $\mathrm{N} \times 6.38$, Kjeldahl method; AOAC International, 2000), CN (AOAC International, 2000), NPN (AOAC International, 2000), total Ca (Park, 2000), and insoluble Ca (ICA) by the acid-base titration method (Lucey et al., 1993; Hassan et al., 2004). The rennet whey was prepared as described in Lucey et al. (1993) and analyzed for soluble Ca content (Park, 2000). The cheese composition was analyzed at 2 wk of ripening for moisture (Marshall, 1992), fat (AOAC International, 2000), protein by the Kjeldahl method (AOAC International, 2000), $\mathrm{pH}$ by directly inserting a spear tip $\mathrm{pH}$ probe (accuCap Capillary Junction $\mathrm{pH}$ combination electrode 13-620-133; Fisher Scientific, Itasca, IL) into cheese curd during manufacture or cheese block, salt by the chloride electrode method (model 926, Corning Glass Works, Medfield, MA; Johnson and Olson, 1985), lactose and lactic acid using HPLC method (Zeppa et 
al., 2001), and total $\mathrm{Ca}$ and $\mathrm{Na}$ by inductively coupled argon plasma emission spectroscopy (Vista-MPX Simultaneous ICP-OES, Varian Inc., Palo Alto, CA; Park, 2000). The ICA content of cheeses were measured at 1 and $4 \mathrm{~d}, 2 \mathrm{wk}$, and 1,3 , and 6 mo by the acid-base titration method and calculated as described by Hassan et al. (2004). All analyses were done in triplicate.

\section{Microbiological Analysis}

Starter lactococci and nonstarter lactobacilli strains were measured by de Man, Rogosa, and Sharpe agar and Rogosa SL medium, respectively (both Difco brand; Becton, Dickinson and Co, Franklin Lakes, NJ); samples were incubated at $32^{\circ} \mathrm{C}$ for $48 \mathrm{~h}$ under anaerobic conditions (Frank and Yousef, 2004; Ozturk et al., 2013a).

\section{Proteolysis and Urea-PAGE Gels}

Proteolysis was monitored by water-soluble nitrogen (WSN) and $12 \%$ trichloroacetic acid-soluble nitrogen (TCASN) levels (AOAC International, 2000). Analyses were performed in duplicate. The breakdown of $\alpha_{\mathrm{s}^{-}}$and $\beta-\mathrm{CN}$ during ripening was monitored with urea-PAGE. Urea-PAGE gels were prepared as described by Ozturk et al. (2013b). Pictures of the gels were analyzed with densitometric analysis using image analysis software (GelAnalyzer 2010 version 1.6; Lazarsoftware, Debrecen, Hungary).

\section{Rheological and Textural Measurements}

Rheological properties of the cheese samples were measured by dynamic small amplitude oscillatory rheology as described by Ozturk et al. (2013a). The storage modulus $\left(\mathbf{G}^{\prime}\right)$, loss modulus $\left(\mathbf{G}^{\prime \prime}\right)$, and loss tangent (LT), which is the ratio between the viscous and the elastic properties of the material $\left(\mathrm{LT}=\mathrm{G}^{\prime \prime} / \mathrm{G}^{\prime}\right)$, were measured during a temperature sweep test from 5 to $85^{\circ} \mathrm{C}$ with the heating rate of $1^{\circ} \mathrm{C} / \mathrm{min}$, a frequency of $0.08 \mathrm{~Hz}$, and strain of $0.5 \%$. The maximum loss tangent (LTmax) value observed during heating was also recorded. We also calculated the temperature where LT $=1$ (i.e., where $\mathrm{G}^{\prime \prime}=\mathrm{G}^{\prime}$ ), as this indicates the transition from a solid to a liquid-like system (i.e., a crossover point). Texture profile analysis (TPA) and uniaxial compression tests were carried out using a TA.XT2 Texture Analyzer (Texture Technologies Corp., Scarsdale, NY) as described by Ozturk et al. (2013a).

\section{Descriptive Sensory Analysis}

Cheese flavor and texture attributes were evaluated with a mixture of Sensory Spectrum and quantitative descriptive analysis (Meilgaard et al., 1999) by $\geq 9$ trained (20 h of training) panelists at 1,3 , and 6 mo of ripening. Cheeses cubes $(2 \times 2 \times 2 \mathrm{~cm})$ were evaluated at $11^{\circ} \mathrm{C}$. Samples were identified with random 3-digit numbers. A 15-point scale was used to evaluate the following attributes: firmness, chewiness, saltiness, acidity, bitterness, as well as metallic, milky, oxidized, and sulfur flavors (Table 2). All sensory panels were conducted in duplicate on 2 different days.

\section{Experimental Design and Statistical Analyses}

Cheeses were manufactured in 5 replicate cheesemaking batches. In each batch, 4 treatments were used: one regular salt $(2 \% \mathrm{NaCl})$ non-UF fortified, no HHP applied (R-Na); 3 low-salt $(0.8 \% \mathrm{NaCl})$, nonUF fortified, no HHP applied (L-Na); UF-fortified, no HHP applied (L-Na-UF); and UF-fortified, HHPtreated (L-Na-UF-HHP; $500 \mathrm{MPa}$ for 3 min applied at $1 \mathrm{~d}$ after cheese manufacture). An ANOVA was carried out using the PROC GLM procedure of SAS (version 9.3; SAS Institute, 2003). Scheffé's multiplecomparison test was used to evaluate differences in the treatments at a significance level of $P<0.05$ for cheese composition.

The effect of treatment (R-Na, L-Na, L-Na-UF, and L-Na-UF-HHP) and ripening time and their interactions on pH, ICA, WSN, TCASN, and textural, rheological, and sensory properties were monitored using a splitplot design. In the whole-plot factor, cheesemaking day was the blocking factor and treatment was analyzed as discontinuous variable. For the split-plot factor, age and the interaction of age and treatment were treated as variables. The interactive term of treatment and cheesemaking day was treated as the error term for the treatment effect. The ANOVA for the split-plot design was carried out using PROC GLM of SAS. Fisher's least significant difference test was carried out to evaluate differences in the treatment means at a significance level of $P<0.05$. Pearson correlation coefficients were estimated between various responses.

\section{RESULTS AND DISCUSSION}

\section{Composition and Microbiology}

Moisture content of $\mathrm{R}-\mathrm{Na}$ Cheddar cheese was lower than that of the L-Na cheeses (Table 3). Previous studies also reported that a reduction in $\mathrm{NaCl}$ increased the moisture content of cheeses (Grant, 2011; Rulikowska et al., 2013), although steps were taken to try to decrease the moisture content of the L-Na cheeses (Table 1). The R-Na cheese exhibited higher S/M and Na contents (Table 3 ), and lower water activity values (results 
Table 2. Definition of the attributes used by the trained panelists to evaluate the texture and flavor of the Cheddar cheeses at $11^{\circ} \mathrm{C}$ using a combination of Spectrum and quantitative descriptive analysis

\begin{tabular}{|c|c|c|}
\hline \multicolumn{3}{|l|}{ Texture } \\
\hline Chewiness $^{1}$ & $\begin{array}{l}\text { The total amount of energy required to masticate the } \\
\text { sample to a state pending swallowing. } \\
\text { Place cheese cube between molars, chew cheese cube at } \\
\text { an even rate, both sides of mouth may be used. Measure } \\
\text { total energy required. }\end{array}$ & $\begin{array}{l}\text { Philadelphia full-fat Cream Cheese (Kraft Foods, } \\
\text { Northfield, IL) }=1.0 \\
\text { Beef frankfurters (Hebrew National Brand, ConAgra Foods } \\
\text { Inc., Omaha, NE) }=4.0 \\
\text { Gum Drops (Dots, Tootsie Roll Industries, Chicago, IL) = } \\
9.0 \\
\text { Beef Jerky (Jack Link's Brand, Minong, WI) }=13.5\end{array}$ \\
\hline \multicolumn{3}{|r|}{ - } \\
\hline Bitter $^{1}$ & Basic taste sensation elicited by bitter compounds & None to pronounced \\
\hline Metallic $^{2}$ & Aromas and flavors associated with metal & None to pronounced \\
\hline
\end{tabular}

${ }^{1}$ Attributes were evaluated using Spectrum analysis.

${ }^{2}$ Attribute was evaluated using quantitative descriptive analysis (Meilgaard et al., 1999).

not shown) compared with all L-Na cheeses, as was expected. No significant $(P>0.05)$ differences were noted in $\mathrm{S} / \mathrm{M}$ and $\mathrm{Na}$ values between all L-Na cheeses.

Use of HHP treatment and UF retentate fortification significantly $(P<0.05)$ increased the $\mathrm{pH}$ values of cheeses (Tables 4 and 5) compared with L-Na cheeses. The $\mathrm{pH}$ value of $\mathrm{L}-\mathrm{Na}-\mathrm{UF}-\mathrm{HHP}$ cheeses was similar or higher than R-Na cheese at all ages, whereas the L-Na cheese exhibited significantly $(P<0.05)$ lower $\mathrm{pH}$ values than $\mathrm{R}-\mathrm{Na}$ or $\mathrm{L}-\mathrm{Na}-\mathrm{UF}-\mathrm{HHP}$ cheeses during ripening (Table 5). The $\mathrm{R}-\mathrm{Na}$ cheese had higher residual lactose (results not shown) and lower lactic acid content than L-Na cheese during ripening (Table $5)$. The L-Na-UF-HHP cheese exhibited significantly $(P<0.05)$ lower lactic acid contents during ripening than L-Na cheese (Table 5). Casal and Gomez (1999) reported that HHP treatment decreased the acidifying activity of lactic acid bacteria. In our experiments, we do not know if the lower lactic acid values of L-Na-UFHHP were due to an impairment in glycolytic pathway or due to the lower numbers of viable starter lactic acid bacteria in L-Na-UF-HHP cheese (Table 5).

Table 3. Composition (mean $\pm \mathrm{SD}$ ) of 2 -wk old Cheddar cheese manufactured with 2 different NaCl levels with or without UF retentate fortification of cheese milk and HHP treatment $(n=5)$

\begin{tabular}{|c|c|c|c|c|}
\hline Item & Regular $\mathrm{NaCl}$ & Low $\mathrm{NaCl}$ & $\begin{array}{l}\text { Low } \mathrm{NaCl} \text {, } \\
\text { UF-fortified }\end{array}$ & $\begin{array}{c}\text { Low } \mathrm{NaCl}, \text { UF-fortified, } \\
\text { HHP treated }\end{array}$ \\
\hline Moisture (\%) & $34.7 \pm 0.7^{\mathrm{bc}}$ & $38.2 \pm 0.8^{\mathrm{a}}$ & $36.0 \pm 0.7^{\mathrm{b}}$ & $36.2 \pm 0.7^{\mathrm{b}}$ \\
\hline Fat $(\%)$ & $34.7 \pm 0.6^{\mathrm{a}}$ & $33.1 \pm 0.5^{\mathrm{b}}$ & $33.9 \pm 0.5^{\mathrm{b}}$ & $33.4 \pm 0.5^{\mathrm{b}}$ \\
\hline Protein (\%) & $25.1 \pm 0.5^{\mathrm{b}}$ & $24.4 \pm 0.4^{\mathrm{c}}$ & $25.9 \pm 0.6^{\mathrm{a}}$ & $26.0 \pm 0.6^{\mathrm{a}}$ \\
\hline Salt in moisture (\%) & $5.8 \pm 0.4^{\mathrm{a}}$ & $2.1 \pm 0.1^{\mathrm{b}}$ & $2.3 \pm 0.2^{\mathrm{b}}$ & $2.2 \pm 0.1^{\mathrm{b}}$ \\
\hline $\operatorname{MNFS}^{2}(\%)$ & $53.2 \pm 0.9^{\mathrm{c}}$ & $57.2 \pm 0.9^{\mathrm{a}}$ & $54.4 \pm 1.2^{\mathrm{b}}$ & $54.4 \pm 0.9^{\mathrm{b}}$ \\
\hline $\mathrm{FDM}^{3}(\%)$ & $53.1 \pm 0.8^{\mathrm{ba}}$ & $53.7 \pm 0.8^{\mathrm{a}}$ & $52.9 \pm 1.1^{\mathrm{ba}}$ & $52.4 \pm 0.9^{\mathrm{b}}$ \\
\hline $\mathrm{NaCl}^{4}(\%)$ & $2.01 \pm 0.20^{\mathrm{a}}$ & $0.80 \pm 0.00^{\mathrm{b}}$ & $0.82 \pm 0.10^{\mathrm{b}}$ & $0.81 \pm 0.10^{\mathrm{b}}$ \\
\hline $\mathrm{Na}^{5}(\mathrm{mg} / 100 \mathrm{~g})$ & $759 \pm 33^{\mathrm{a}}$ & $278 \pm 21^{\mathrm{b}}$ & $282 \pm 17^{\mathrm{b}}$ & $273 \pm 22^{\mathrm{b}}$ \\
\hline $\mathrm{Ca}^{5}(\mathrm{mg} / 100 \mathrm{~g})$ & $694 \pm 39^{\mathrm{a}}$ & $660 \pm 25^{\mathrm{a}}$ & $698 \pm 26^{\mathrm{a}}$ & $695 \pm 27^{\mathrm{a}}$ \\
\hline
\end{tabular}

${ }^{\mathrm{a}-\mathrm{c}}$ Means within the same row not sharing a common superscript differ $(P<0.05)$.

${ }^{1} \mathrm{HHP}=$ high-hydrostatic pressure; $500 \mathrm{MPa}$ for $3 \mathrm{~min}$ at $6.4 \pm 1{ }^{\circ} \mathrm{C}$, performed on cheeses obtained from this vat, at $1 \mathrm{~d}$ of age.

${ }^{2} \mathrm{MNFS}=$ moisture in nonfat substance.

${ }^{3} \mathrm{FDM}=$ fat in dry matter.

${ }^{4}$ Determined using salt analyzer.

${ }^{5}$ Determined using ICP method (Park, 2000). 
Pressure treatment decreased starter culture numbers by $\sim 2$ and $\sim 4.5 \log$ at $4 \mathrm{~d}$ and 2 wk of ripening, respectively, compared with all other cheeses (Tables 4 and 5 ). Higher water activity in cheese has been reported to result in greater bacterial inactivation by HHP (Morales et al., 2006). At lower water activity, enhanced survival of bacterial cells may be due to their tendency toward cell shrinkage resulting in the thickening of the cell membrane (Goh et al., 2007). The combination of low $\mathrm{pH}(<5.0)$ and reduced ionic strength could have been contributory factors responsible for the greater reduction in viable starter numbers between $4 \mathrm{~d}$ and 2 wk by HHP in the lower-salt cheeses (Martinez-Rodriguez et al., 2012). Starter bacteria numbers of L-Na-UF-HHP cheese slowly recovered but remained $\sim 2 \log$ lower than $\mathrm{R}-\mathrm{Na}$ cheese and low- $\mathrm{NaCl}$ cheeses (L-Na and L-NaUF) until 3 and 6 mo of ripening, respectively.

Rulikowska et al. (2013) reported that the $\mathrm{NaCl}$ level significantly influenced initial (1 d) starter number in Cheddar cheese. In our study, $\mathrm{NaCl}$ level did not significantly $(P>0.05)$ influence the starter culture numbers; R-Na, L-Na, and L-Na-UF cheeses exhibited similar starter culture numbers during ripening (Table $5)$. The likely explanation for the difference between Rulikowska et al. (2013) and our study was that the starter culture strains that we used were very sensitive to the S/M levels in our cheeses. Swearingen et al. (2004) reported that various types of starter cultures used for Cheddar cheese manufacture in the United States exhibited a wide range of salt sensitivities. The growth rate of nonstarter lactic acid bacteria was unaffected by $\mathrm{NaCl}$ content, UF retentate fortification, or HHP treatment during ripening (results not shown). Lane et al. (1997) reported that $\mathrm{S} / \mathrm{M}$ levels $\leq 5.9 \%$ did not significantly influence the overall nonstarter lactic acid bacteria numbers in Cheddar cheese.

\section{ICA Levels}

Salt content and UF retentate fortification significantly $(P<0.05)$ influenced ICA levels in Cheddar cheese samples (Table 4). The L-Na cheese exhibited significantly $(P<0.05)$ lower ICA values compared with R-Na cheese during the initial $(\leq 14 \mathrm{~d})$ of ripening (Figure 1). Cheese $\mathrm{pH}$ affects the amount of ICA in cheese. Calcium in the insoluble form (or bound to $\mathrm{CN}$ ) is solubilized with a decrease in cheese $\mathrm{pH}$ (Lucey et al., 2003). The lower $\mathrm{pH}$ values of $\mathrm{L}-\mathrm{Na}$ cheese (Table 5) was likely responsible for their lower levels of ICA compared with $\mathrm{R}-\mathrm{Na}$ cheeses. The $\mathrm{pH}$ values of cheese were significantly positively correlated $(P<0.05)$ with ICA levels with a correlation coefficient of 0.78 . The LNa-UF and L-Na-UF-HHP cheeses did not significantly $(P>0.05)$ differ in ICA values compared with $\mathrm{R}-\mathrm{Na}$ cheese. Previous studies reported that cheeses manufactured with UF retentate-fortified cheese milk resulted in cheeses with higher buffering capacities (Kosikowski, 1983), which is positively correlated with ICA levels (Hassan et al., 2004). Our results also indicated that cheeses manufactured from UF retentate-fortified milks had slightly higher ICA levels during ripening than L-Na cheeses (Figure 1), even though the total Ca concentrations were similar in all cheeses. The LNa-UF-HHP cheese exhibited significantly $(P<0.05)$ higher $\mathrm{pH}$ values compared with L-Na-UF up to 1 mo of ripening. The ICA values in these cheeses were similar during ripening. Previous studies indicated that HHP might not change the overall ICA levels in cheese (Ozturk et al., 2013b), although reports in milk systems indicated that complete solubilization of ICA occurred during HHP, but the solubilization was mostly reversed upon pressure removal (Schrader et al., 1997).

\section{Proteolysis}

Water-soluble $\mathrm{N}$ is an indicator of primary proteolysis in cheese (Rank et al., 1985). The level of $\mathrm{NaCl}$ did not significantly $(P>0.05)$ influence the concentration of WSN (Figure 2a). Starting from 1 mo of ripening, LNa-UF-HHP cheese exhibited significantly $(P<0.05)$ lower levels of W-SN (Figure 2a, Table 4), indicating a reduction in residual coagulant activity. Previous studies also suggested that application of pressures $>400$ $\mathrm{MPa}$ decreased residual calf chymosin activity (Malone et al., 2003; Juan et al., 2007). The aspartic proteinase family exhibit high sequence identity (Chitpinityol and Crabbe, 1998), thus camel and calf chymosins were likely to be similarly affected by HHP treatment.

Activity of both residual rennet, and microbial proteases and peptidases contribute to the levels of TCASN in cheeses (Rank et al., 1985). The L-Na cheese exhibited significantly $(P<0.05)$ higher TCASN levels compared with R-Na cheese during 1 mo of ripening (Figure 2b). Fox (1970) reported that CN (especially $\alpha_{\mathrm{s} 1}-\mathrm{CN}$ ) had increased rates of proteolysis with a decrease in the level of insoluble calcium phosphate crosslinking between $\mathrm{CN}$. The activity of residual chymosin on $\alpha_{\mathrm{s} 1^{-}}$and $\beta-\mathrm{CN}$ is reportedly highest at $\mathrm{pH}$ values $\leq 5.0$ (Mulvihill and Fox, 1978; Grappin et al., 1985). The higher initial levels of TCASN values in L-Na cheese compared with R-Na cheese could be partly due to its lower $\mathrm{pH}$ values as well as lower ICA levels. The L-Na-UF-HHP cheese did not significantly $(P>0.05)$ differ from R-Na cheese in TCASN values until 1 mo of ripening. After 1 mo of ripening, L-Na-UF-HHP exhibited significantly $(P<0.05)$ lower levels of TCASN compared with all other cheeses, regardless of UF retentate fortification or $\mathrm{NaCl}$ content (Figure $2 \mathrm{~b}$ ). Pressure 
FORTIFICATION AND HIGH-PRESSURE TREATMENT OF CHEDDAR

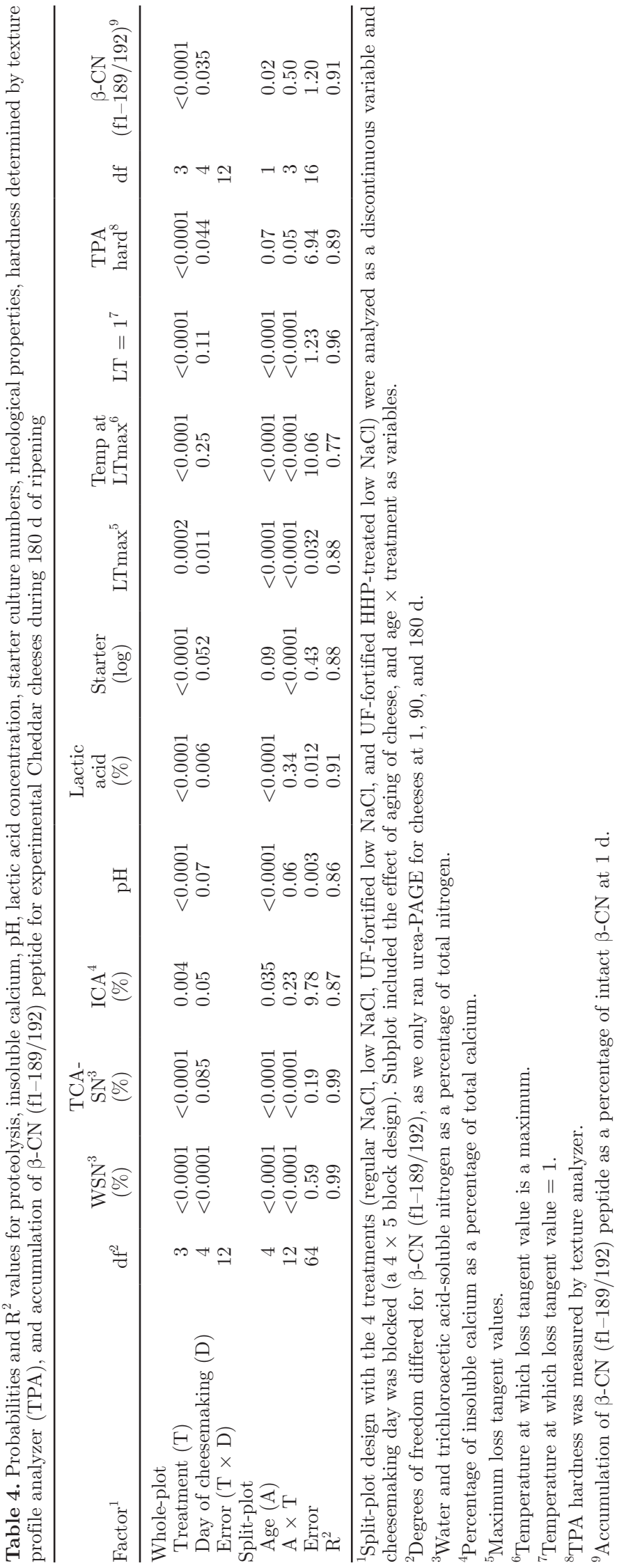




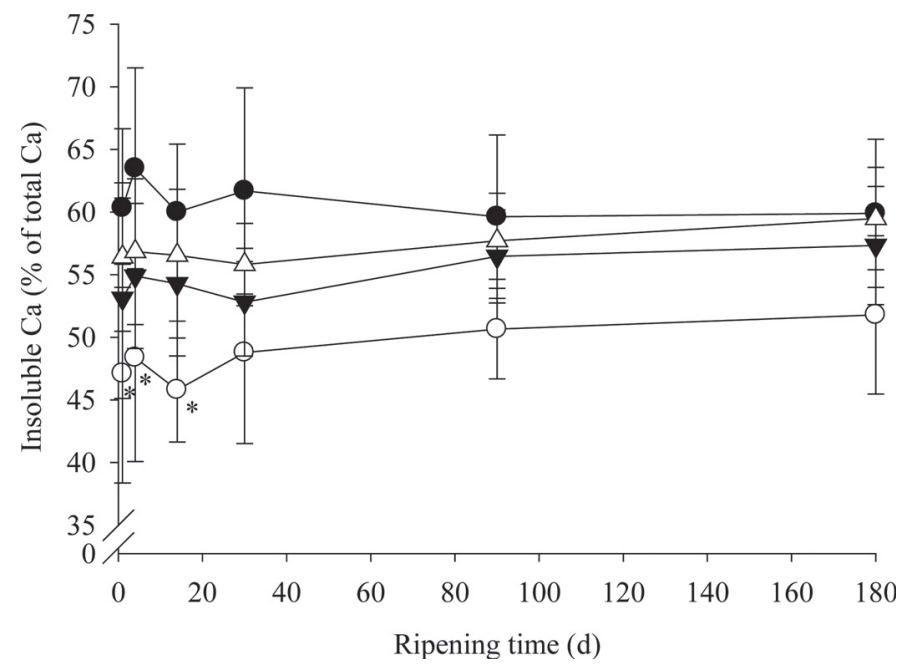

Figure 1. Insoluble calcium, expressed as a percentage of total calcium, for regular $\mathrm{NaCl}(\bullet)$; low- $\mathrm{NaCl}(\bigcirc)$, UF-fortified, low $\mathrm{NaCl}$ $(\mathbf{\nabla})$; and UF-fortified, high-hydrostatic pressure-treated, low- $\mathrm{NaCl}$ $(\Delta)$ Cheddar cheeses during $180 \mathrm{~d}$ of ripening at $7^{\circ} \mathrm{C}$. Vertical bars represent SD. An asterisk $\left.{ }^{*}\right)$ represents a significant $(P<0.05)$ difference from regular $\mathrm{NaCl}$ cheese at the indicated ripening time point.

treatment significantly decreased the number of viable starter bacteria by about $2 \log$ in our study (Table 5 ). Malone et al. (2003) reported that pressures $\geq 500 \mathrm{MPa}$ decreased the activity or completely inactivated some of the major proteolytic enzymes in cheese matrix (i.e., residual chymosin and starter proteases or peptideases, such as, cell envelope protease, X-prolyl-dipeptidyl aminopeptidase, and aminopeptidase N). Thus, the significantly $(P<0.05)$ lower levels of TCASN observed for L-Na-UF-HHP cheese suggested a decrease in the activities of both microbial proteases/peptidases and residual chymosin as a result of HHP treatment.

Urea-PAGE electrophoretogram of cheese samples during ripening is shown in Figure 3. The hydrophobic $\beta-\mathrm{CN}$ (f1-189/192) and $\beta-\mathrm{CN}$ (f193-209) peptides are products formed from the $\mathrm{C}$-terminal region of $\beta$ - $\mathrm{CN}$ as a result of chymosin action on the $\mathrm{Leu}_{192}-\mathrm{Tyr}_{193}$ bond (Visser and Slanger, 1977). $\beta$-Casein (f193-209) peptide and some of its degradation products have been identified as significant contributors of bitterness in cheese (Visser et al., 1983). Although $\beta-\mathrm{CN}$ (f1-189/192) is not bitter, the presence of this peptide suggests other bitter peptides, such as $\beta$-CN (f193-209) peptide and some of its degradation products, are also present in the cheese.

Salt content and HHP treatment significantly $(P<$ $0.05)$ influenced the intensity of this $\beta$-CN (f1-189) peptide in the experimental cheeses (Figure 3, Figure 4a). The R-Na and L-Na-UF-HHP samples exhibited significantly $(P<0.05)$ lower levels of this peptide compared with L-Na and L-Na-UF samples at 3 and 6 mo of ripening (Figure $4 \mathrm{a}$ ). The concentration of $\mathrm{NaCl}$ (S/M) significantly influences residual coagulant activity in cheese (Guinee and Fox, 2004). Previous studies have also reported that the production of this $\beta-\mathrm{CN}$ (f1-189/192) peptide during cheese ripening was significantly increased with a decrease in the $\mathrm{NaCl}$ level (Kelly et al., 1996; Moller et al., 2013; Ozturk et al., $2013 \mathrm{~b}$ ). Degradation of $\alpha_{\mathrm{s} 1}-\mathrm{CN}$ was also significantly ( $P$ $<0.05)$ lower for L-Na-UF-HHP cheese compared with all other cheeses after 3 mo of ripening (Figure $4 \mathrm{~b}$ ). Level of $\mathrm{NaCl}$ did not significantly $(P>0.05)$ influence the degradation of $\alpha_{\mathrm{s} 1^{-}} \mathrm{CN}$; R-Na cheese exhibited

Table 5. Starter bacteria numbers, $\mathrm{pH}$, and lactic acid (wt/wt, \%) values for regular-NaCl (R-Na); low$\mathrm{NaCl}$ (L-Na); UF-fortified, low-NaCl (L-Na-UF); and UF-fortified, HHP-treated, low-NaCl (L-Na-UF HHP) Cheddar cheeses during $180 \mathrm{~d}$ of ripening ${ }^{1}$

\begin{tabular}{llcccc}
\hline \multirow{2}{*}{ Item } & $\begin{array}{l}\text { Ripening } \\
\text { time }(\mathrm{d})\end{array}$ & R-Na & L-Na & L-Na-UF & L-Na-UF-HHP ${ }^{2}$ \\
\hline Starter (log cfu/g) & 4 & $8.9^{\mathrm{a}}$ & $9.0^{\mathrm{a}}$ & $9.0^{\mathrm{a}}$ & $7.0^{\mathrm{b}}$ \\
& 14 & $9.0^{\mathrm{a}}$ & $9.3^{\mathrm{a}}$ & $9.2^{\mathrm{a}}$ & $4.8^{\mathrm{b}}$ \\
& 30 & $8.9^{\mathrm{a}}$ & $9.4^{\mathrm{a}}$ & $9.2^{\mathrm{a}}$ & $5.2^{\mathrm{b}}$ \\
& 90 & $8.2^{\mathrm{b}}$ & $9.1^{\mathrm{a}}$ & $9.1^{\mathrm{a}}$ & $6.5^{\mathrm{c}}$ \\
$\mathrm{pH}$ & 180 & $7.6^{\mathrm{ab}}$ & $8.7^{\mathrm{a}}$ & $8.6^{\mathrm{a}}$ & $5.22^{\mathrm{a}}$ \\
& 4 & $5.13^{\mathrm{a}}$ & $4.94^{\mathrm{c}}$ & $5.06^{\mathrm{b}}$ & $5.23^{\mathrm{a}}$ \\
& 14 & $5.12^{\mathrm{b}}$ & $4.99^{\mathrm{c}}$ & $5.09^{\mathrm{b}}$ & $5.21^{\mathrm{a}}$ \\
& 30 & $5.22^{\mathrm{a}}$ & $5.01^{\mathrm{b}}$ & $5.16^{\mathrm{ab}}$ & $5.24^{\mathrm{a}}$ \\
Lactic acid & $9.26^{\mathrm{a}}$ & $5.01^{\mathrm{b}}$ & $5.16^{\mathrm{ab}}$ & $5.29^{\mathrm{a}}$ \\
& 180 & $5.27^{\mathrm{a}}$ & $5.09^{\mathrm{b}}$ & $5.23^{\mathrm{a}}$ & $1.03^{\mathrm{b}}$ \\
& 4 & $0.70^{\mathrm{c}}$ & $1.28^{\mathrm{a}}$ & $1.16^{\mathrm{ab}}$ & $1.48^{\mathrm{b}}$ \\
& 14 & $0.88^{\mathrm{c}}$ & $1.40^{\mathrm{a}}$ & $1.25^{\mathrm{b}}$ & $1.46^{\mathrm{b}}$ \\
& 30 & $1.17^{\mathrm{c}}$ & $1.62^{\mathrm{a}}$ & $1.50^{\mathrm{ab}}$ & $1.61^{\mathrm{b}}$ \\
\hline
\end{tabular}

${ }^{\mathrm{a}-\mathrm{c}}$ Means within the same row not sharing a common superscript differ $(P<0.05)$.

${ }^{1}$ Values are means $(\mathrm{n}=5)$.

${ }^{2} \mathrm{HHP}=$ high-hydrostatic pressure, $500 \mathrm{MPa}$ for $3 \mathrm{~min}$ at $6.4 \pm 1^{\circ} \mathrm{C}$, performed on cheese at $1 \mathrm{~d}$ of age 

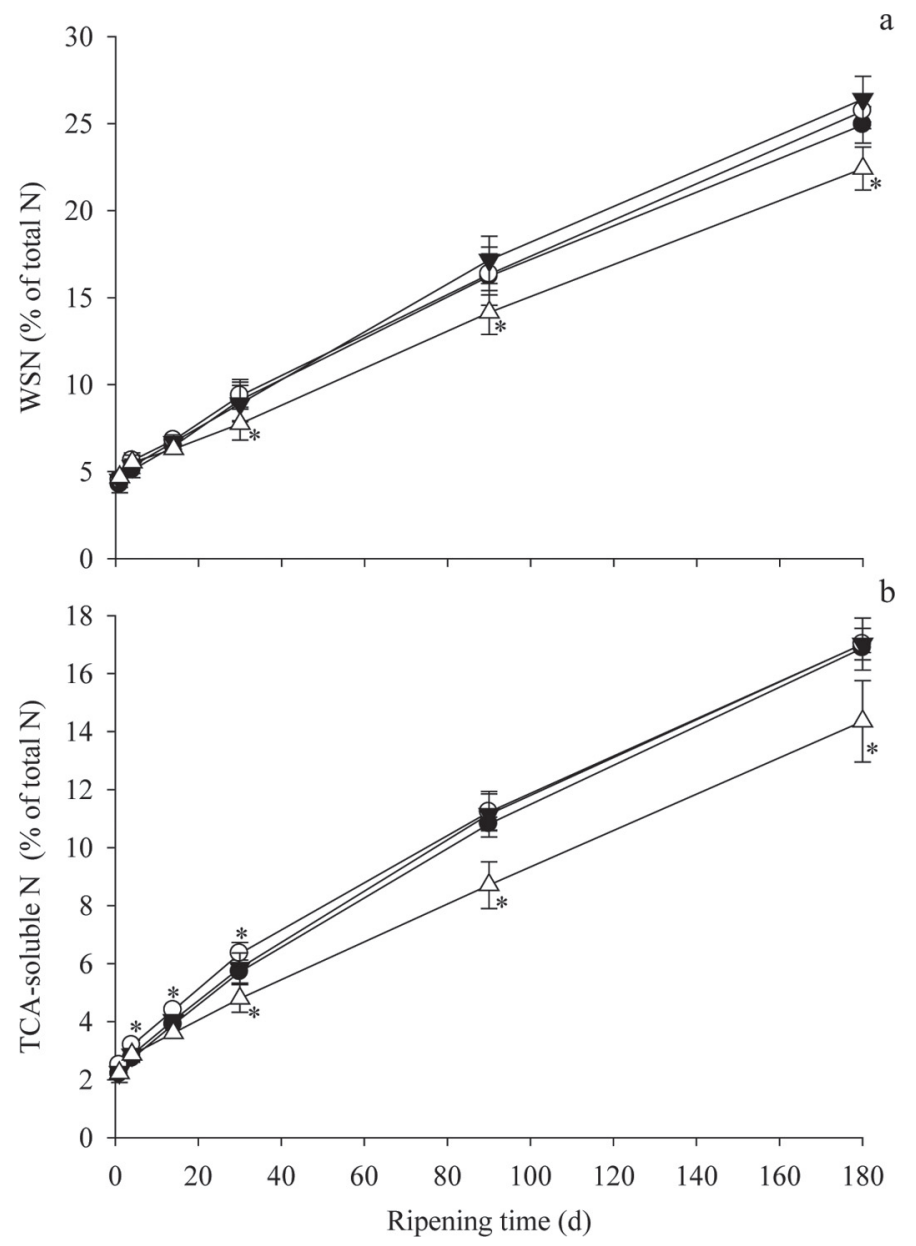

Figure 2. Water-soluble nitrogen (a) and trichloroacetic acid-soluble nitrogen (b) as a percentage of total nitrogen values for regular $\mathrm{NaCl}(\bullet)$; low- $\mathrm{NaCl}(\bigcirc)$; UF-fortified, low- $\mathrm{NaCl}(\mathbf{v})$; and UF-fortified, high-hydrostatic pressure-treated, low- $\mathrm{NaCl}(\Delta)$ Cheddar cheeses during $180 \mathrm{~d}$ of ripening at $7^{\circ} \mathrm{C}$. Vertical bars represent SD. An asterisk $(*)$ represents a significant $(P<0.05)$ difference from regular $\mathrm{NaCl}$ cheese at the indicated ripening time point.

similar levels of intact $\alpha_{\mathrm{s} 1}$-CN compared with L-Na and L-Na-UF cheeses during ripening (Figure 3, Figure 4b). Fox and Walley (1971) reported that only very high concentrations of $\mathrm{NaCl}$ (15 and 20\%) decreased the activity of chymosin on $\alpha_{\mathrm{s} 1}-\mathrm{CN}$.

\section{Rheological Properties}

High-pressure treatment and $\mathrm{NaCl}$ level significantly $(P<0.05)$ affected the rheological properties of cheese samples (Table 4). The crossover point of the graph of $\mathrm{G}^{\prime}$ and $\mathrm{G}^{\prime \prime}$ (where the LT $=1$ ) is used as an indicator of melting temperature (Lucey et al., 2003). The R-Na cheese exhibited the highest melting temperature during ripening, whereas L-Na-UF-HHP cheese had the lowest (Figure 5a). Previous studies have suggested that HHP treatment weakens the hydrophobic interactions in cheese and decreases the melting temperature (Messens et al., 2000; Ozturk et al., 2013a,b). Fortification of cheese milk with UF retentate did not influence the melting temperature of L-Na cheeses during the first 3 mo of ripening. However, the melting temperature of L-Na cheese significantly increased $(P<0.05)$ from 3 to 6 mo of ripening, whereas the melting temperature of L-Na-UF cheese did not change. Similar trends in melting temperature of L-Na Cheddar cheese during ripening were previously reported (Grant, 2011; Ozturk et al., 2013b).

The LTmax values are another indicator of cheese meltability, with higher LTmax values indicating more fluid or liquid-like characteristics during heating (Lucey et al., 2003). The L-Na-UF-HHP cheese exhibited significantly $(P<0.05)$ higher LTmax values at 4 d compared with all other cheeses and then hardly changed during the rest of the ripening period (Figure 5b). All cheeses exhibited similar LTmax values at 90 d (Figure 5b). Acharya and Mistry (2004) reported that cheese meltability decreased with an increase in the concentration of TS in the cheese milk; however, Govindasamy-Lucey et al. (2005) overcame this issue by addition of the amount of starter cultures and coagulant proportional to the $\mathrm{CN}$ content of cheese milk. In cheesemaking, the addition of coagulant proportional to the $\mathrm{CN}$ content of milk helped to produce similar rates of proteolysis in fortified and unfortified milks (Figure 2a).

At 6 mo of ripening, L-Na cheese exhibited significantly $(P<0.05)$ lower LTmax values compared with all other treatments. For L-Na cheeses at 3 and 6 mo of age, the $\mathrm{G}^{\prime}$ values slightly increased at temperatures $>70^{\circ} \mathrm{C}$, indicating a strengthening of some type of protein interactions (Figure 6). None of the other cheese samples exhibited this increase in $G^{\prime}$ values at high temperatures (results not shown). The decrease in LTmax for L-Na cheese observed at 6 mo was also unusual because cheese meltability is expected to increase with age due to the effect of proteolysis (Lucey et al., 2003). Several cheese studies have also reported an increase in $\mathrm{G}^{\prime}$ values of cheese at high temperatures (Lee et al., 2005; Grant, 2011; Ozturk et al., 2013b). The cheese samples in these studies had either low $\mathrm{pH}$ values or low S/M content (or both); this may indicate that electrostatic interactions may play an important role in modulating the rheological properties at high temperatures. Lee et al. (2005) reported that the $\mathrm{G}^{\prime}$ values of low pH Cheddar cheeses measured at 5,40 , and $80^{\circ} \mathrm{C}$ $(\mathrm{pH}$ values $<5.0)$ increased during ripening (from 4 to $12 \mathrm{wk}$ ), even though the $\mathrm{pH}$ or ICA values did not exhibit any significant change. Grant (2011) reported the $\mathrm{G}^{\prime}$ values exhibited an increase at high temperatures at $\geq 3$ mo of ripening for Cheddar cheese made with 


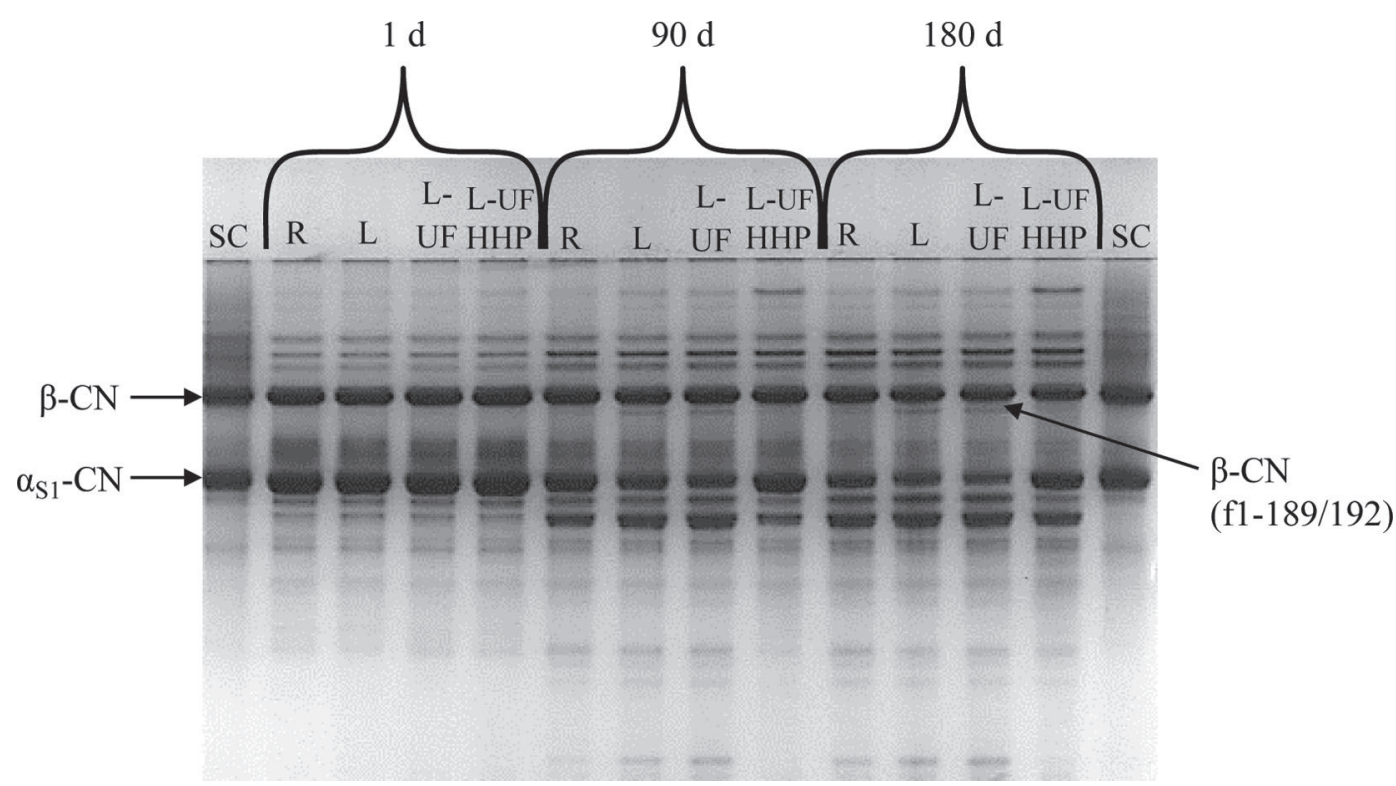

Figure 3. Urea-PAGE electrophoretograms showing the breakdown of caseins in regular-NaCl (R); low-NaCl (L); UF-fortified, low-NaCl (L UF); and UF-fortified, high-hydrostatic pressure-treated, low-NaCl (L UF HHP) Cheddar cheeses at 1, 90, and $180 \mathrm{~d}$ of ripening at $7^{\circ} \mathrm{C}$. Lanes with SC refer to sodium caseinate (standard).

$2.1 \% \mathrm{~S} / \mathrm{M}$ content. Lucey at al. (2003) suggested that decreased electrostatic repulsion between $\mathrm{CN}$ in low$\mathrm{pH}(\mathrm{pH}<5)$ cheeses led to increased protein-protein (e.g., hydrophobic) interactions and, thereby, less melt. Low ionic strength also increases the rate of interaction of renneted CN micelles (Horne and Lucey, 2014). We speculated that the decrease in LTmax values of L-Na cheese at 6 mo of ripening may be related to enhanced hydrophobic interactions at high temperature that were promoted by proteolysis (possible due to hydrolysis of some charged peptides), as well as facilitated by the low $\mathrm{pH}$ and low ionic strength.

\section{Textural Properties}

At all ripening periods, $\mathrm{R}-\mathrm{Na}$ samples exhibited higher TPA hardness values $(P<0.05)$ compared with all L-Na cheeses (Figure 7). Some minor differences were noted in moisture content among cheeses. However, even though the moisture content of $\mathrm{R}-\mathrm{Na}$ and L-Na-UF cheeses were not significantly different (Table $3)$, the R-Na cheese was significantly $(P<0.05)$ harder even at $4 \mathrm{~d}$. Previous studies also indicated that a reduction in $\mathrm{NaCl}$ decreased cheese hardness (Pastorino et al., 2003; Grant, 2011) even when moisture contents of cheeses were adjusted by cheesemaking conditions so that the L-Na cheeses were similar to R-Na cheeses (Grant, 2011; Moller et al., 2012). Up until 1 mo of ripening, L-Na-UF cheese exhibited significantly $(P$ $<0.05$ ) higher hardness values compared with both L-Na-UF-HHP and L-Na cheeses. Kosikowski (1983) also reported that UF retentate fortification of cheese milk increased the hardness in reduced $\mathrm{NaCl}$ Cheddar cheese. The ICA content is one factor that could affect cheese hardness (Lucey et al., 2003). Ultrafiltered retentate fortification of cheese milk increased the initial ICA level for the L-Na-UF cheese compared with the L-Na cheeses (Figure 1), resulting in higher initial hardness values. Even though L-Na-UF-HHP cheese was also manufactured with UF retentate-fortified milk, it exhibited similar hardness values compared with L-Na cheese at each ripening time point (Figure 7). Previous studies suggested that HHP treatment decreased cheese hardness (measured shortly after HHP treatment) via a reduction in hydrophobic interactions within the protein network (Messens et al., 2000; Ozturk et al., 2013a). All L-Na cheese treatments exhibited similar hardness values after 1 mo.

Uniaxial compression (obtained from 80\% compression of cheese) profiles showed that L-Na cheeses exhibited higher strain to fracture during $1 \mathrm{mo}$ of ripening compared with R-Na cheese (results not shown). Ozturk et al. (2013b) also reported an increase in fracture strain with salt reduction in Cheddar cheese. Previous studies suggested that, as salt content increased, cheeses became harder, shorter, and more brittle (Guinee, 2004; Guinee and Fox, 2004). From 3 mo of age, L-NaUF and L-Na-UF-HHP cheeses exhibited fracture at significantly $(P<0.05)$ higher strains compared with L-Na and R-Na cheeses (results not shown). Lucey et al. (2003) reported that cheese $\mathrm{pH}$ is closely related to the strain at fracture. As the electrostatic repulsion be- 

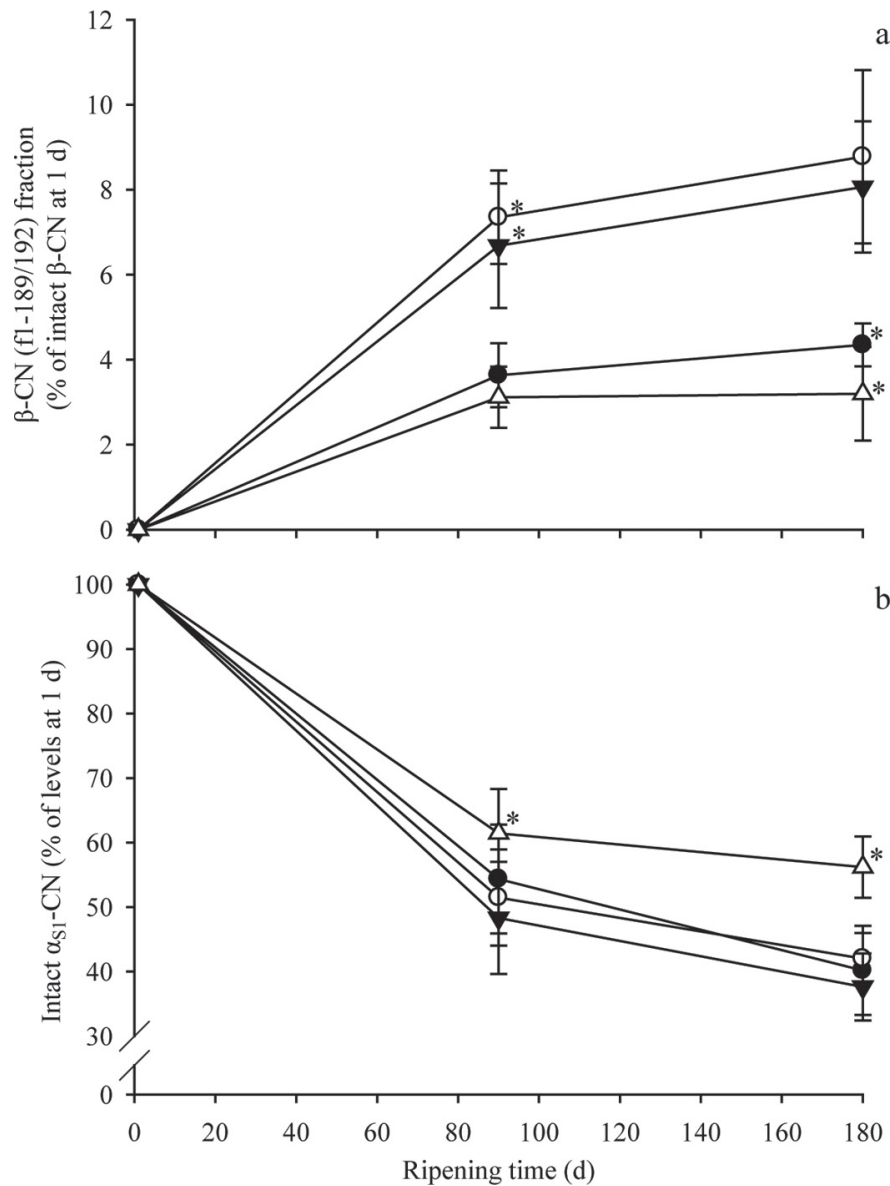

Figure 4. Accumulation of $\beta-\mathrm{CN}$ (f1-189/192) fraction as a percentage of the intact $\beta$-CN level at $1 \mathrm{~d}$ (a), and level of intact $\alpha_{\mathrm{s1}}{ }^{-} \mathrm{CN}$ as a percentage of its level at $1 \mathrm{~d}$ (b) calculated from area (pixel intensity) by the GelAnalyzer program (Lazarsoftware, Debrecen, Hungary) from the urea-polyacrylamide gels for regular- $\mathrm{NaCl}(\bullet)$; low- $\mathrm{NaCl}(\bigcirc)$; UF-fortified, low-NaCl ( $\mathbf{\nabla})$; and UF-fortified, high-hydrostatic pressure-treated, low-NaCl $(\Delta)$ Cheddar cheeses at 1,90 , and $180 \mathrm{~d}$ of ripening at $7^{\circ} \mathrm{C}$. Vertical bars represent SD. An asterisk (*) represents a significant $(P<0.05)$ difference from regular $\mathrm{NaCl}$ cheese at the indicated ripening time point.

tween $\mathrm{CN}$ decreases, cheese becomes short and brittle (Lucey et al., 2003). The decrease in fracture strain of $\mathrm{L}-\mathrm{Na}$ cheese with ripening could be due to its lower $\mathrm{pH}$ values compared with L-Na-UF cheeses.

\section{Sensory Analysis}

Sensory texture and flavor attributes of the cheeses are shown in Table 6. Sensory firmness, salt, acidic, bitter, and metallic attributes were all significantly influenced by the treatments (Table 7). Panelists scored the R-Na cheese significantly $(P<0.05)$ firmer than all the L-Na cheeses (Table 6), in agreement with the instrumental TPA results (Figure 7). Fortification with UF retentate or HHP treatment did not significantly $(P$
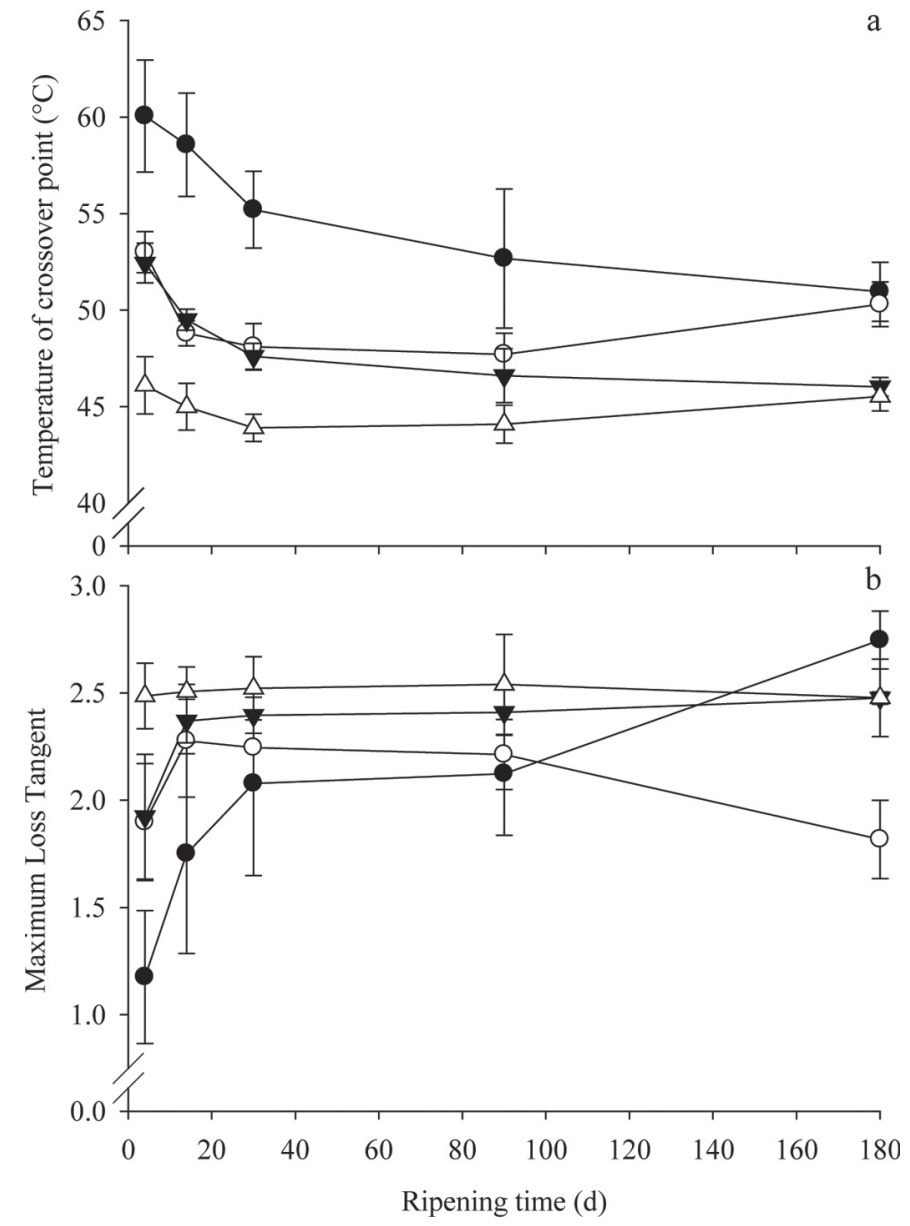

Figure 5. Temperature of the crossover point of the storage and loss moduli graphs (or where LT $=1 ; \mathrm{a}$ ), and the maximum loss tangent values (b) for regular- $\mathrm{NaCl}(\bullet)$; low- $\mathrm{NaCl}(\bigcirc)$; UF-fortified, low$\mathrm{NaCl}(\boldsymbol{\nabla})$; and UF-fortified, high-hydrostatic pressure-treated, low$\mathrm{NaCl}(\Delta)$ Cheddar cheeses during $180 \mathrm{~d}$ of ripening at $7^{\circ} \mathrm{C}$. Vertical bars represent SD.

$>0.05)$ influence the sensory firmness of L-Na cheese samples. Sensory chewiness values of all cheeses were not affected by $\mathrm{NaCl}$ level, fortification with UF retentate, or HHP treatment (results not shown).

The R-Na cheese received significantly $(P<0.05)$ higher scores for saltiness compared with all L-Na cheeses (Table 6), as expected. The L-Na cheese possessed more acid flavor than the R-Na or the L-NaUF-HHP cheese at 1, 3, and 6 mo (Table 6), which corresponded to its lower $\mathrm{pH}$ and higher lactic acid content (Table 5). The acid intensities of L-Na-UF and L-Na-UF-HHP cheeses were similar to the R-Na cheeses during ripening. In general, all samples developed only very low bitterness values $(<2.5$ on a 15 -point scale) during ripening. Previous studies also reported that cheeses manufactured with camel chymosin exhibited lower levels of bitterness compared with cheeses made with calf chymosin (Govindasamy-Lucey et al., 2010; 


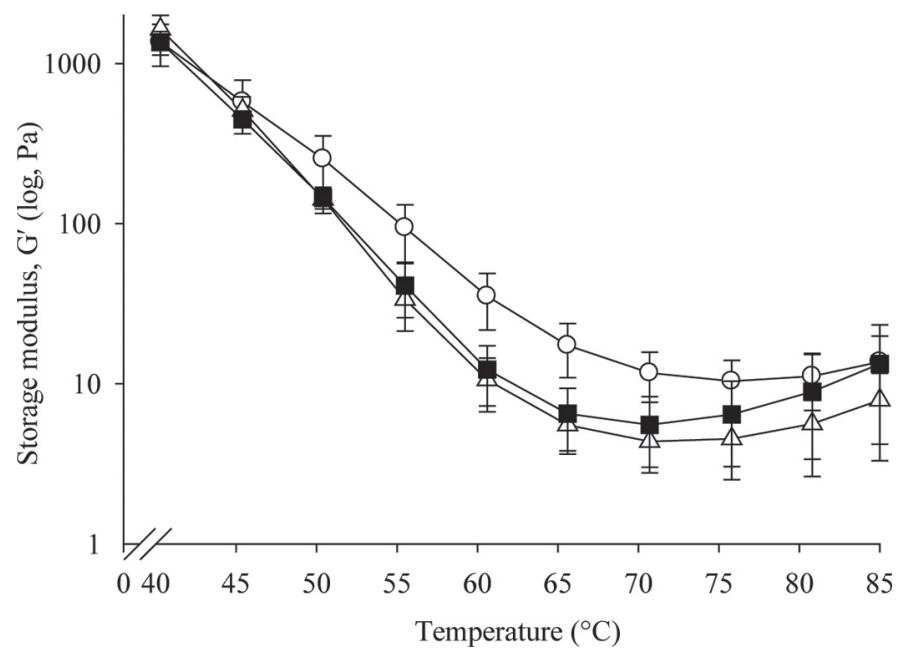

Figure 6. Storage modulus $\left(\mathrm{G}^{\prime}\right)$ as a function of temperature for low- $\mathrm{NaCl}$ cheese at $4 \mathrm{~d}(\bigcirc)$, and $3(\Delta)$ and 6 mo (ם). Cheese was heated from 5 to $85^{\circ} \mathrm{C}$ at $1^{\circ} \mathrm{C} / \mathrm{min}$. Vertical bars represent SD.

Grant, 2011). The L-Na-UF-HHP cheese did not significantly $(P>0.05)$ differ from R-Na cheese in bitterness scores at 3 or 6 mo of ripening, whereas the L-Na cheese were significantly $(P<0.05)$ more bitter than $\mathrm{R}-\mathrm{Na}$ cheese (Tables 6 and 7 ). The L-Na-UF cheese exhibited bitterness scores intermediate between L-Na and L-Na-UF-HHP cheeses. The lower level of bitterness in L-Na-UF-HHP cheese was in agreement with the reduced levels of $\beta$-CN (f1-189/192) peptide (Figure 3, Figure 4a) in this cheese, suggesting that bitter peptides such as $\beta$-CN (f193-209) peptide and some of

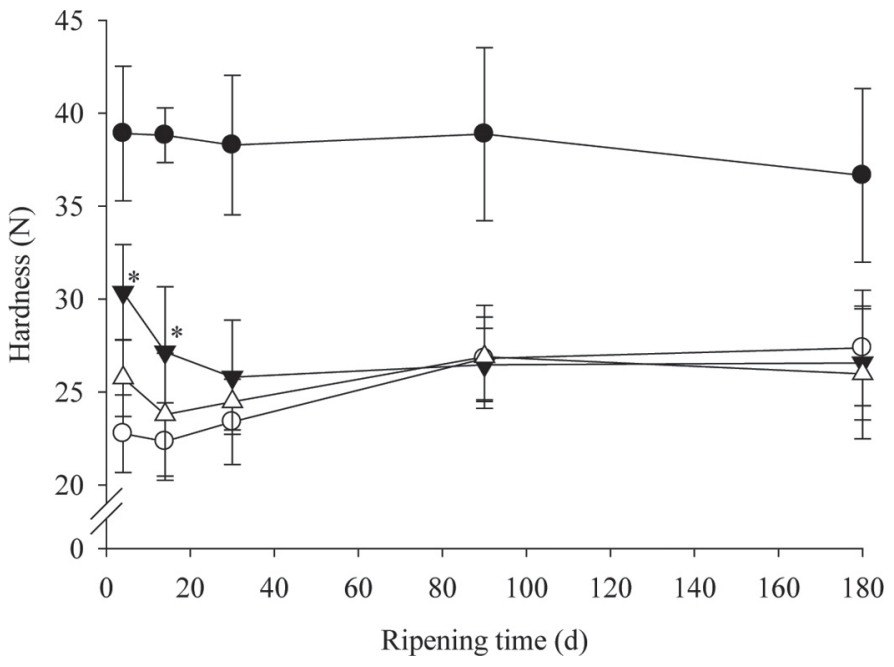

Figure 7. Hardness (N) from texture profile analysis testing $(20 \%$ compression of cheese cylinders compared with original height) for regular- $\mathrm{NaCl}(\bullet)$; low-NaCl $(\bigcirc)$; UF-fortified, low-NaCl ( $\mathbf{\nabla})$; and UFfortified, high-hydrostatic pressure-treated, low-NaCl $(\Delta)$ Cheddar cheeses during $6 \mathrm{mo}$ of ripening at $7^{\circ} \mathrm{C}$. Vertical bars represent SD. An asterisk $(*)$ represents a significant $(P<0.05)$ difference from low$\mathrm{NaCl}$ cheese at the indicated ripening time point.

its degradation products were present in reduced levels in this cheese. No significant differences in sweetness values were observed in any cheese sample (results not shown). Panelists perceived a metallic note $(<1.8$ on a 15 -point scale) in all samples (Table 7$)$. During ripening, the metallic taste was significantly $(P<0.05)$ higher for L-Na cheese compared with R-Na cheese. At 6 mo of ripening, L-Na cheese exhibited significantly

Table 6. Sensory texture and flavor intensities (on 0-15 point scale) for regular- $\mathrm{NaCl}$ (R-Na); low-NaCl (L$\mathrm{Na}$ ); UF-fortified, low-NaCl (L-Na-UF); and UF-fortified, HHP-treated, low-NaCl (L-Na-UF HHP) Cheddar cheeses evaluated at 1,3 , and 6 mo of ripening ${ }^{1}$

\begin{tabular}{llrrrr}
\hline $\begin{array}{l}\text { Ripening } \\
\text { Time }\end{array}$ & Attribute & R-Na & L-Na & L-Na-UF & L-Na-UF-HHP ${ }^{2}$ \\
\hline \multirow{2}{*}{$1 \mathrm{mo}$} & Firmness & $13.2^{\mathrm{a}}$ & $10.9^{\mathrm{b}}$ & $11.4^{\mathrm{b}}$ & $11.3^{\mathrm{b}}$ \\
& Salt & $5.5^{\mathrm{a}}$ & $2.9^{\mathrm{b}}$ & $2.6^{\mathrm{b}}$ & $2.5^{\mathrm{b}}$ \\
& Acid & $4.0^{\mathrm{b}}$ & $5.3^{\mathrm{a}}$ & $4.5^{\mathrm{b}}$ & $4.1^{\mathrm{b}}$ \\
& Bitter & $0.4^{\mathrm{a}}$ & $0.6^{\mathrm{a}}$ & $0.6^{\mathrm{a}}$ & $0.5^{\mathrm{a}}$ \\
& Metallic & $0.6^{\mathrm{b}}$ & $1.0^{\mathrm{a}}$ & $0.7^{\mathrm{b}}$ & $0.7^{\mathrm{b}}$ \\
& Firmness & $13.2^{\mathrm{a}}$ & $11.9^{\mathrm{b}}$ & $11.5^{\mathrm{b}}$ & $11.6^{\mathrm{b}}$ \\
& Salt & $5.8^{\mathrm{a}}$ & $3.3^{\mathrm{b}}$ & $3.0^{\mathrm{b}}$ & $2.8^{\mathrm{b}}$ \\
& Acid & $4.7^{\mathrm{b}}$ & $6.0^{\mathrm{a}}$ & $5.4^{\mathrm{b}}$ & $1.0^{\mathrm{bc}}$ \\
& Bitter & $0.7^{\mathrm{c}}$ & $1.6^{\mathrm{a}}$ & $1.3^{\mathrm{ba}}$ & $1.3^{\mathrm{a}}$ \\
& Metallic & $1.0^{\mathrm{b}}$ & $1.3^{\mathrm{a}}$ & $1.3^{\mathrm{a}}$ & $11.6^{\mathrm{b}}$ \\
& Firmness & $13.0^{\mathrm{a}}$ & $11.9^{\mathrm{b}}$ & $11.5^{\mathrm{b}}$ & $3.3^{\mathrm{b}}$ \\
& Salt & $5.7^{\mathrm{a}}$ & $3.5^{\mathrm{b}}$ & $3.5^{\mathrm{b}}$ & $4.8^{\mathrm{b}}$ \\
& Acid & $4.8^{\mathrm{b}}$ & $5.7^{\mathrm{a}}$ & $5.2^{\mathrm{ba}}$ & $1.6^{\mathrm{b}}$ \\
& Bitter & $1.2^{\mathrm{b}}$ & $2.4^{\mathrm{a}}$ & $2.2^{\mathrm{a}}$ & $1.5^{\mathrm{b}}$ \\
& Metallic & $1.3^{\mathrm{b}}$ & $1.8^{\mathrm{a}}$ & $1.5^{\mathrm{b}}$ &
\end{tabular}

${ }^{\mathrm{a}-\mathrm{c}}$ Means within the same row not sharing a common superscript differ $(P<0.05)$.

${ }^{1}$ Values are means $(\mathrm{n}=5)$.

${ }^{2} \mathrm{HHP}=$ high-hydrostatic pressure, $500 \mathrm{MPa}$ for $3 \mathrm{~min}$ at $6.4 \pm 1{ }^{\circ} \mathrm{C}$, performed on cheese at $1 \mathrm{~d}$ of age 
Table 7. Probabilities and $\mathrm{R}^{2}$ values for the sensory attributes firmness, salt, acid bitter, and metallic for Cheddar cheeses evaluated during $180 \mathrm{~d}$ of ripening

\begin{tabular}{|c|c|c|c|c|c|c|}
\hline Factor $^{1}$ & df & Firmness & Salt & Acid & Bitter & Metallic \\
\hline Treatment $(\mathrm{T})$ & 3 & $<0.0001$ & $<0.0001$ & 0.0005 & $<0.0001$ & $<0.0001$ \\
\hline Day of cheesemaking (D) & 4 & 0.01 & 0.002 & 0.82 & 0.011 & 0.22 \\
\hline \multicolumn{7}{|l|}{ Split-plot } \\
\hline Age (A) & 2 & 0.003 & $<0.0001$ & $<0.0001$ & $<0.0001$ & $<0.0001$ \\
\hline $\mathrm{A} \times \mathrm{T}$ & 6 & 0.001 & 0.18 & 0.93 & 0.11 & 0.32 \\
\hline
\end{tabular}

${ }^{1}$ Split-plot design with the 4 treatments (regular $\mathrm{NaCl}$, low $\mathrm{NaCl}$, UF-fortified low $\mathrm{NaCl}$, and UF-fortified high-hydrostatic pressure-treated low $\mathrm{NaCl}$ ) were analyzed as a discontinuous variable and cheesemaking day was blocked (a $4 \times 5$ block design). Subplot included the effect of aging of cheese, and age $\times$ treatment as variables.

$(P<0.05)$ higher metallic taste compared with R-Na, L-Na-UF, and L-Na-UF-HHP cheeses (Table 7). The L-Na cheeses have often been reported to exhibit more off-flavors than R-Na cheeses (Grant, 2011; Rulikowska et al., 2013; Moller et al., 2013).

\section{CONCLUSIONS}

High-pressure treatment and cheese milk fortification with UF retentate significantly affected the texture, rheology, microflora, and sensory properties of $\mathrm{L}-\mathrm{Na}$ cheese. Rheological and textural properties of $\mathrm{L}-\mathrm{Na}$ cheese made with UF retentate were altered after HHP treatment and remained fairly unchanged during 6 mo of ripening. These results indicated that 500-MPa HHP treatment helped to minimize ripening (age)-related changes in the properties of L-Na cheese. Starter culture numbers significantly decreased with HHP treatment, whereas the $\mathrm{NaCl}$ content did not influence the number of starter bacteria present in the experimental cheeses during ripening. Pressure application decreased the levels of WSN, TCASN, and the production of $\beta-C N$ (f1-189/192) peptide observed during ripening. Fortification of cheese milk with UF retentate helped prevent L-Na cheeses from exhibiting an excessive $\mathrm{pH}$ drop, which may be due to their higher ICA phosphate content (greater buffering). Fortification of cheese milk with UF retentate increased initial cheese hardness (i.e., until 1 mo of ripening), which could be helpful in improving the initial soft texture typical of L-Na cheeses but did not match the firmness of R-Na cheeses even when its gross chemical composition $(\mathrm{pH}$, moisture and protein contents) were similar to those of $\mathrm{R}-\mathrm{Na}$ cheeses. The reduction in the rate of proteolysis and microbial numbers as a result of HHP treatment could help to provide increase shelf-life for L-Na cheeses. The combination of HHP and UF retentate fortification were helpful approaches to improve the quality of L-Na cheese.

\section{ACKNOWLEDGMENTS}

The authors thank the Wisconsin Center for Dairy Research and University of Wisconsin Dairy Plant (Madison, WI) personnel for their assistance in cheesemaking, analytical work, and sensory analyses. We also thank American Pasteurization Company (APC, Milwaukee, WI) for their help and support in the high-pressure processing of the cheeses. We also thank DuPont USA Inc. (Madison, WI) and Chr. Hansen Inc. (Milwaukee, WI) for their donation of starter cultures and coagulants used in this study. The financial support of the Dairy Management Inc. (Rosemont, IL) and Wisconsin Milk Marketing Board (Madison, WI) are greatly appreciated.

\section{REFERENCES}

Acharya, M. R., and V. V. Mistry. 2004. Comparison of effect of vacuum-condensed and ultrafiltered milk on Cheddar cheese. J. Dairy Sci. 87:4004-4012.

AOAC International. 2000. Official Methods of Analysis. 17th ed. AOAC International, Arlington, VA.

Casal, V., and R. Gomez. 1999. Effect of high pressure on the viability and enzymatic activity of mesophilic lactic acid bacteria isolated from caprine cheese. J. Dairy Sci. 82:1092-1098.

Chitpinityol, S., and M. J. Crabbe. 1998. Chymosin and aspartic proteinases. Food Chem. 61:395-418.

Fox, P. F. 1970. Influence of aggregation on the susceptibility of casein to proteolysis. J. Dairy Res. 37:173-180.

Fox, P. F., and B. F. Walley. 1971. Influence of sodium chloride on the proteolysis of casein by rennet and by pepsin. J. Dairy Res. $38: 165-170$.

Frank, J. F., and A. E. Yousef. 2004. Tests for groups of microorganisms. Pages 227-247 in Standard Methods for the Examination of Dairy Products. 17th ed. H. M. Wehr and J. F. Frank, ed. American Public Health Association, Washington, DC.

Goh, E. L. C., A. D. Hocking, C. M. Stewart, K. A. Buckle, and G. H. Fleet. 2007. Baroprotective effect of increased solute concentrations on yeasts and moulds during high pressure processing. Innov. Food Sci. Emerg. Technol. 8:535-542.

Govindasamy-Lucey, S., J. J. Jaeggi, M. E. Johnson, T. Wang, and J. A. Lucey. 2005. Use of cold ultrafiltered retentates for standardization of milks for pizza cheese: Impact on yield and functionality. Int. Dairy J. 15:941-955.

Govindasamy-Lucey, S., Y. Lu, J. J. Jaeggi, M. E. Johnson, and J. A. Lucey. 2010. Impact of camel chymosin on the texture and sensory 
properties of low-fat Cheddar cheese. Aust. J. Dairy Technol. 65:139-142.

Grant, K. V. 2011. Impact of sodium chloride reduction on the compositional, functional, and flavor properties of full-fat Cheddar cheese. MS Thesis. Univ. of Wisconsin-Madison.

Grappin, R., T. C. Rank, and N. F. Olson. 1985. Primary proteolysis of cheese proteins during ripening. A review. J. Dairy Sci. 68:531-540.

Green, W. C., and K. K. Park. 1980. Comparison of AOAC, microwave and vacuum oven methods for determining total solids in milk. J. Food Prot. 4:782-783.

Grummer, J., N. Bobowski, M. Karalus, Z. Vickers, and T. Schoenfuss. 2013. Use of potassium chloride and flavor enhancers in low sodium Cheddar cheese. J. Dairy Sci. 96:1401-1418.

Guinee, T. P. 2004. Salting and the role of salt in cheese. Int. J. Dairy Technol. 57:99-109.

Guinee, T. P., and P. F. Fox. 2004. Salt in cheese: Physical, chemical and biological aspects. Pages 207-259 in Cheese: Chemistry, Physics and Microbiology. Vol. 1. P. F. Fox, ed. Chapman and Hall, London, UK.

Hassan, A., M. E. Johnson, and J. A. Lucey. 2004. Changes in the proportions of soluble and insoluble calcium during the ripening of Cheddar cheese. J. Dairy Sci. 87:854-862.

Horne, D. S., and J. A. Lucey. 2014. Revisiting the temperature dependence of the coagulation of renneted bovine casein micelles. Food Hydrocoll. 42:75-80.

IOM (Institute of Medicine). 2005. Dietary Reference Intakes for Water, Potassium, Sodium, Chloride, and Sulfate. Natl. Acad. Press, Washington, DC.

Johnson, M. E., R. Kapoor, D. J. McMahon, D. R. McCoy, and R. G. Narasimmon. 2009. Reduction of sodium and fat levels in natural and processed cheeses: Scientific and technological aspects. Compr. Rev. Food Sci. Food Safety 8:252-268.

Johnson, M. E., and N. F. Olson. 1985. A comparison of available methods for determining salt levels in cheese. J. Dairy Sci. 68:1020-1024.

Juan, B., V. Ferragut, M. Buffa, B. Guamis, and A. Trujillo. 2007. Effects of high pressure on proteolytic enzymes in cheese: Relationship with the proteolysis of ewe milk cheese. J. Dairy Sci. 90:2113-2125.

Kelly, M., P. F. Fox, and P. L. H. McSweeney. 1996. Effect of saltin-moisture on proteolysis in Cheddar-type cheese. Milchwissenschaft 51:498-501.

Kosikowski, F. V. 1983. Low sodium Cheddar cheeses through whole milk retentate supplementation. J. Dairy Sci. 66:2494-2500.

Lane, C. N., P. F. Fox, E. M. Walsh, B. Folkersma, and P. L. H. McSweeney. 1997. Effect of compositional and environmental factors on the growth of indigenous non-starter lactic acid bacteria in Cheddar cheese. Lait 77:561-573.

Lee, M. R., M. E. Johnson, and J. A. Lucey. 2005. Impact of modifications in acid development on the insoluble calcium content and rheological properties of Cheddar cheese. J. Dairy Sci. 88:37983809 .

Lindsay, R. C., S. M. Hargett, and S. C. Bush. 1982. Effect of sodium/ potassium (1:1) chloride and low sodium chloride concentrations on quality of Cheddar cheese. J. Dairy Sci. 65:360-370.

Lucey, J. A., B. Hauth, C. Gorry, and P. F. Fox. 1993. The acid-base buffering properties of milk. Milchwissenschaft 48:268-272.

Lucey, J. A., M. E. Johnson, and D. S. Horne. 2003. Perspectives on the basis of the rheology and texture properties of cheese. J. Dairy Sci. 86:2725-2743

Malone, A. S., C. Wick, T. H. Shellhammer, and P. D. Courtney. 2003. High pressure effects on proteolytic and glycolytic enzymes involved in cheese manufacturing. J. Dairy Sci. 86:1139-1146.

Marshall, R. T. 1992. Standard Methods for the Examination of Dairy Products. 16th ed. American Public Health Association, Washington, DC.

Martinez-Rodriguez, Y., C. Acosta-Muniz, G. I. Olivas, J. GuerreroBeltran, D. Rodrigo-Aliaga, and D. R. Sepulveda. 2012. High hy- drostatic pressure processing of cheese. Compr. Rev. Food Sci Food Safety 11:399-416.

Meilgaard, M. M., G. V. Civille, and B. T. Carr. 1999. Selection and training of panel members. Pages 174-176 in Sensory Evaluation Techniques. 3rd ed. CRC Press, Boca Raton, FL.

Messens, W., D. Van de Walle, J. Arevalo, K. Dewettinck, and A. Huyghebaert. 2000. Rheological properties of high-pressure-treated Gouda cheese. Int. Dairy J. 10:359-367.

Moller, K. K., F. P. Rattray, and Y. Ardo. 2013. Application of selected lactic acid bacteria and coagulant for improving the quality of low-salt Cheddar cheese: Chemical, microbiological and rheological evaluation. Int. Dairy J. 33:163-174.

Moller, K. K., F. P. Rattray, E. Høier, and Y. Ardo. 2012. Manufacture and biochemical characteristics during ripening of Cheddar cheese with variable $\mathrm{NaCl}$ and equal moisture content. Dairy Sci. Technol. 92:543-568.

Morales, P., J. Calzada, B. Rodriguez, M. de Paz, P. Gaya, and M. Nunez. 2006. Effect of cheese water activity and carbohydrate content on the barotolerance of Listeria monocytogenes Scott A. J. Food Prot. 69:1328-1333.

Mulvihill, D. M., and P. F. Fox. 1978. Proteolysis of bovine $\beta$-casein by chymosin: Influence of $\mathrm{pH}$, urea and sodium chloride. Int. J. Food Sci. Technol. 2:135-139.

Ozturk, M., S. Govindasamy-Lucey, J. J. Jaeggi, K. Houck, M. E. Johnson, and J. A. Lucey. 2013a. Impact of various high pressure treatments on the properties of reduced fat Cheddar cheese. J. Dairy Sci. 96:6792-6806.

Ozturk, M., S. Govindasamy-Lucey, J. J. Jaeggi, M. E. Johnson, and J. A. Lucey. 2013b. The influence of high hydrostatic pressure on regular, reduced, low and no salt added Cheddar cheese. Int. Dairy J. 33:175-183.

Park, Y. W. 2000. Comparison of mineral and cholesterol composition of different commercial goat milk products manufactured in USA. Small Rumin. Res. 37:115-124.

Pastorino, A. J., C. L. Hansen, and D. J. McMahon. 2003. Effect of salt on structure-function relationships in cheese. J. Dairy Sci. 86:60-69.

Rank, T. C., R. Grappin, and N. F. Olson. 1985. Secondary proteolysis of cheese during ripening: A review. J. Dairy Sci. 64:801-805.

Rulikowska, A., K. N. Kilcawley, I. A. Doolan, M. Alonso-Gomez, A. B. Nongonierma, J. A. Hannon, and M. G. Wilkinson. 2013. The impact of reduced sodium chloride content on Cheddar cheese quality. Int. Dairy J. 28:45-55.

SAS Institute. 2003. SAS User's Guide: Statistics. Version 9.3. SAS Institute Inc., Cary, NC

Schrader, K., W. Buchheim, and C. V. Morr. 1997. High pressure effects on the colloidal calcium phosphate and the structural integrity of micellar casein. Nahrung 41:133-138.

Swearingen, P. A., D. E. Adams, and T. L. Lensmire. 2004. Factors affecting calcium lactate and liquid expulsion defects in Cheddar cheese. J. Dairy Sci. 87:574-582.

Taylor, R. S., K. E. Ashton, T. Moxham, L. Hooper, and S. Ebrahim. 2011. Reduced dietary salt for the prevention of cardiovascular disease: A review. Cochrane Database Syst. Rev. 7:CD009217.

US Department of Health and Human Services. 2005. Dietary Guidelines for Americans. Accessed Mar. 1, 2014. http://www.health. gov/dietaryguidelines/dga2005/document/.

Visser, S., G. Hup, F. A. Exterkate, and J. Stadhouders. 1983. Bitter flavour in cheese. 2. Model studies on the formation and degradation of bitter peptides by proteolytic enzymes from calf rennet, starter cells and starter cell fractions. Neth. Milk Dairy J. $37: 169-180$.

Visser, S., and K. J. Slanger. 1977. On the Specificity of chymosin (renin) in its action on $\beta$-casein. Neth. Milk Dairy J. 31:16-30.

Zeppa, G., L. Conterno, and V. Gerbi. 2001. Determination of organic acids, sugars, diacetyl, and acetoin in cheese by high-performance liquid chromatography. J. Agric. Food Chem. 49:2722-2726. 